\title{
Analysis of Genetic Potential of Banyuwangi Local Rice (Oryza sativa L.) Based on Relative Expression of Homogentisate Geranylgeranyl Transferase (HGGT) and Granule-Bound Starch Synthase I (GBSSI) Gene
}

\author{
Dyati Galuh Pratita1, ${ }^{1}$, Tita Putri Milasari ${ }^{1,3}$, Elhah Nailul Khasna ${ }^{3}$, Sunarmi ${ }^{1}$, Evi Susanti ${ }^{2}$, Suharti ${ }^{2,3}$, Delia Wahyu \\ Pangesti ${ }^{1,3}$, Annasa Sabatia ${ }^{1,3}$, Dwi Listyorini ${ }^{1,3^{*}}$ \\ 'Department of Biology, Faculty of Mathematics and Natural Sciences, Universitas Negeri Malang, Malang, Indonesia \\ ${ }^{2}$ Department of Chemistry, Faculty of Mathematics and Natural Sciences, Universitas Negeri Malang, Malang, Indonesia \\ ${ }^{3}$ Biotechnology Division, Central Laboratory of Mineral and advanced Material, Faculty of Mathematics and Natural Sciences, \\ Universitas Negeri Malang, Malang, Indonesia
}

ARTICLE INFO

\section{Article history:}

Received October 13, 2020

Received in revised form March 5, 2021

Accepted March 12, 2021

\section{KEYWORDS:}

Oryza sativa L., gene expression, qRT-PCR,

HGGT,

GBSSI

\begin{abstract}
Rice nutrition including vitamin and amylose contents become important aspect for many people around the world. Rice with high amylose content (low glycemic index) is good for those with Diabetes mellitus. Tocotrienol, one precursor of Vitamin-E biosynthesis is catalyzed by enzymes encoded $H G G T$, while amylose biosynthesis is catalyzed by enzymes encoded GBSSI. The objective of this study was to find rice varieties with high tocotrienol and/or amylose content based on the expression of $H G G T$ and $G B S S I$ among eight Banyuwangi local rice varieties. Relative expression of $H G G T$ and $G B S S I$ was measured by qRT-PCR and analyzed using $2^{\Delta C t}$ method. Statistical analysis resulted in the significantly different of $H G G T$ and $G B S S I$ relative expression among samples. Relative expression of HGGT from the highest to the lowest were demonstrated by Hitam Melik, Hitam Pekat, Blambangan A3, Merah Bali, Blambangan A2, Berlian, Janur Kuning, and SOJ A3, respectively; while relative expression of $G B S S I$ from the highest to the lowest were demonstrated by Hitam Melik, Hitam Pekat, SOJ A3, Janur Kuning, Berlian, Merah Bali, Blambangan A3, and Blambangan A2, respectively. Based on this research we conclude that Hitam Melik potentially produces higher tocotrienol and lower glycemic index than other studied varieties.
\end{abstract}

\section{Introduction}

Rice, one of the food crops, is consumed by more than half of world's population, especially in Asia(Milovanovic and Smutka 2017). Rice has been developed in Indonesia, even several local rice varieties have been identified and registered officially, including Hitam Melik, Hitam Pekat, Blambangan A3, Merah Bali, Blambangan A2, Berlian, Janur Kuning, and Sunrise of Java A3. Nutritional quality of rice needs to be considered, such as the content of tocotrienols acting as strong antioxidants (Wang et al. 2018) and amylose affecting the rice glycemic index (Pandey et al. 2012).

Rice has different levels of tocotrienol in each variety (Dian et al. 2018). The gene that plays an important

* Corresponding Author

E-mail Address: listyorini.aljabari@um.ac.id role in tocotrienol biosynthesis is Homogentisate Geranylgeranyl Transferase (HGGT) which encodes HGGT enzyme to catalyze the condensation reaction of geranylgeranyl diphosphate (GGDP) with homogenticic acid into 2-methyl-6-geranylgeranyl benzoquinol which will be converted into four tocotrienol isomers (Zhang et al. 2013; Comitato et al. 2017). Tocotrienols in rice that we consume have antioxidant activity which can neutralize free radicals before causing lipid oxidation or DNA damage (Aggarwal et al. 2010; Kannappan et al. 2012; Miyazawa et al. 2019) and display potent anticancer (Sylvester et al. 2010).

Furthermore, rice which has low glycemic index is also good for health (Pandey et al. 2012). Rice with low glycemic index is characterized by a higher percentage of amylose than amylopectin (Denardin et al. 2012; Jeevetha et al. 2014). Amylose biosynthesis involves Granule Bound Starch Synthase I (GBSSI) that encode 
GBSSI enzyme to catalyze the process of converting glucose-1-phosphate adenyl transferase (ADP-glucose) into amylose (Ruan et al. 2010; Ordonio and Matsuoka 2016).

The amount of tocotrienol in rice is influenced by the level of HGGT gene expression (Dian et al. 2018), while the amount of amylose is influenced by the level of GBSSI gene expression (Ordonio and Matsuoka 2016). The level of expression of both HGGT and GBSSI genes in cells can be measured using Real Time PCR technique and analyzed by the $2^{\Delta \mathrm{Ct}}$ method (Kozera and Rapacz 2013; Šárka and Dvořáček 2017). High level of gene expression produce high end products, therefore this research aims to find rice varieties potentially produce high tocotrienol and/or amylose based on expression of HGGT and GBSSI among eight Banyuwangi local rice varieties.

\section{Materials and Methods}

This research was done in Biotechnology Division, Central Laboratory of Mineral and Advanced Material, Faculty of Mathematics and Natural Sciences, University State of Malang in August 2018 to January 2019. The object of this research was mature seed of eight Banyuwangi local rice varieties including Hitam Melik, Hitam Pekat, Blambangan A3, Merah Bali, Blambangan A2, Berlian, Janur Kuning, and Sunrise of Java A3 obtained from local farmer group in Singojuruh, Banyuwangi, East Java.

\subsection{Total RNA Synthesis}

Total RNA was isolated from $200 \mathrm{mg}$ mature rice seeds ground with mortar and pestle. Total RNA isolation was done using QIAzol Kit. Total RNA quantity and quality were measured using Scientific Nanodrop Spectrophotometer 2000.

\section{2. cDNA Synthesis}

cDNA was synthesized from total RNA using Reverse TOYOBO Kit. Thermal cycler profile for cDNA synthesis was $37^{\circ} \mathrm{C}$ for $15 \mathrm{~min}, 50^{\circ} \mathrm{C}$ for $15 \mathrm{~min}$, and $98^{\circ} \mathrm{C}$ for 15 min. cDNA quantity and quality was measured using Thermo Scientific Nanodrop Spectrophotometer 2000. The primers used in this research are shown in Table 1.

\subsection{Gene Expression Analysis Using RealTime PCR}

HGGT and GBSSI relative expression was analyzed from cDNA using Rotor Gene Q Series thermal cycler and SensiFAST SYBR No-Rox Kit. Thermal cycler software was set at 50 cycles for all three genes. The temperature and duration settings are shown in Table 2.

\subsection{Data Analysis}

Cycle threshold $(\mathrm{Ct})$ values obtained from the real time PCR process were analyzed using $2^{\Delta \mathrm{Ct}}$ method to find out the relative expression of HGGT and GBSSI (Kozera and Rapacz 2013). Both HGGT and GBSSI relative expressions were presented in bar charts using GraphPad Prism 5 software, tested statistically using JMP 6 software.

\section{Results}

\subsection{HGGT Gene Expression}

Based on the result of $2^{\Delta c t}$ data, the relative expressions of HGGT in eight Banyuwangi local rice

Table 1. HGGT, GBSSI, and $\beta$-Actin primer sequences

\begin{tabular}{lll}
\hline Gene & \multicolumn{1}{c}{ Forward primer } & \multicolumn{1}{c}{ Reverse primer } \\
\hline HGGT & 5'-TTTCAAATCACCCACCGTCAG-3' & 5'-TAGGAGCATACAGTTTAGAGCA-3' \\
GBSSI & 5'-AGGCATCGAGGGTGAGGAG-3' & 5'-CCATCTGGCCCACATCTCTA-3' \\
$\beta$-Actin & 5'-CTCAGGAGGAGCAATGATC-3' & 5'-GACCTGTACGCCAACACAG-3' \\
\hline
\end{tabular}

Table 2. Real-time PCR settings

\begin{tabular}{|c|c|c|c|}
\hline Gene & Stage & Temperature $\left({ }^{\circ} \mathrm{C}\right)$ & Duration (minutes) \\
\hline \multirow[t]{3}{*}{ HGGT } & Activation & 95 & 5 \\
\hline & Annealling & 55 & 30 \\
\hline & Denaturation & 95 & 10 \\
\hline \multirow[t]{3}{*}{ GBSS } & Activation & 95 & 5 \\
\hline & Annealling & 56.8 & 30 \\
\hline & Denaturation & 95 & 10 \\
\hline \multirow[t]{3}{*}{$\beta$-Actin } & Activation & 95 & 5 \\
\hline & Annealling & 55 & 30 \\
\hline & Denaturation & 95 & 10 \\
\hline
\end{tabular}


from the highest to the lowest were Hitam Melik $\left(2^{\Delta \mathrm{Ct}}=16.989542\right)$, Hitam Pekat $\left(2^{\Delta \mathrm{Ct}}=5.376001\right)$, Blambangan A3 ( $\left.2^{\Delta \mathrm{Ct}}=4.943469\right)$, Merah Bali $\left(2^{\Delta \mathrm{Ct}}=\right.$ 3.479590), Blambangan A2 $\left(2^{\Delta \mathrm{Ct}}=2.599881\right)$, Berlian $\left(2^{\Delta \mathrm{Ct}}=1.290429\right)$, and Janur Kuning $\left(2^{\Delta \mathrm{Ct}}=1.173945\right)$ respectively (Figure 1 ).

\subsection{GBSSI Gene Expression}

Based on the result of $2^{\Delta \mathrm{Ct}}$ data, the relative expressions of GBSSI in eight Banyuwangi local rice from the highest to the lowest were Hitam Melik ( $2^{\Delta \mathrm{Ct}}$ $=3,333.3)$, Hitam Pekat $\left(2^{\Delta \mathrm{Ct}}=1,844.8\right)$, SOJ A3 $\left(2^{\Delta \mathrm{Ct}}\right.$ $=1,086)$, Janur Kuning $\left(2^{\Delta \mathrm{Ct}}=649.9\right)$, Berlian $\left(2^{\Delta \mathrm{Ct}}=\right.$ 571.3), Merah Bali $\left(2^{\Delta \mathrm{Ct}}=20.2\right)$, Blambangan A3 $\left(2^{\Delta \mathrm{Ct}}\right.$ $=2.4)$, dan Blambangan $\mathrm{A} 2\left(2^{\Delta \mathrm{Ct}}=0.8\right)$ respectively (Figure 2).

Statistical analysis resulted on the significantly different (Chi-Square Value>Prob. Value) relative expression of HGGT and GBSSI among samples (Table 3).

\section{Discussion}

High relative expression of HGGT in Hitam Melik indicates that this variety is able to synthesize tocotrienol more than other varieties because the HGGT codes homogentisate geranylgeranyl transferase (HGGT) enzyme to catalyze condensation process of geranylgeranyl diphosphat (GGDP) and

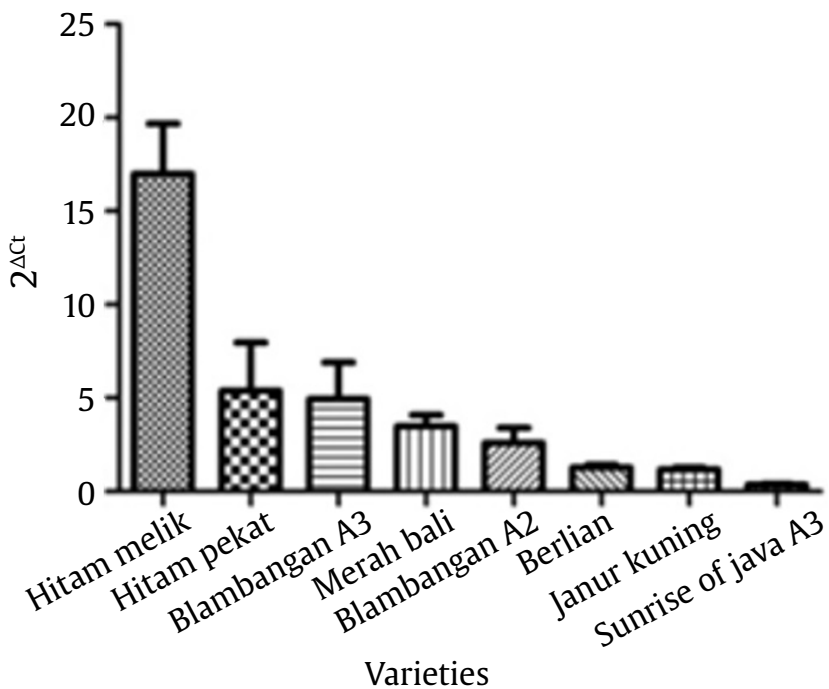

Figure 1. Relative expression of HGGT in eight Banyuwangi local rice varieties homogentisate acid into 2-methyl-6-geranylgeranyl benzoquinol (MGGBQ) in plastid. Furthermore, MGGBQ was changed into four isomers of tocotrienol (Mène-Saffrané and DellaPenna 2010; Zhang et al. 2013; Comitato et al. 2017).

Blambangan A3 and Merah Bali rice seed are reddish so that they commonly known as red rice. They have HGGT relative expression higher than the other varieties (except Hitam Melik and Hitam Pekat). The reddish colour of rice seed is suspected to be a $\beta$-caroten pigment, while the white seed has no pigment. The reddish colour corelates with total tocotrienol which is produced by the same promoting substance (refers to GGDP) from tocotrienol and $\beta$-caroten biosynthesis in mevalonate pathway (Zhang et al. 2013), therefore Blambangan A3 and Merah Bali potentially produce tocotrienol more than other varieties (except Hitam Melik and Hitam Pekat). Furthermore, red rice contains total vitamin E more that came from red part of rice seed caryopsis layer than white seed rice (Shammugasamy et al. 2015). The lowest relative expression of HGGT gene was found in SOJ A3. This variety is commonly called Genjah Harum which has lower total tocotrienol than Hitam Melik and Merah Harum (Blambangan A3) (Dian et al. 2018). When the relative expression of HGGT is low, the HGGT enzyme biosynthesis will decreases (Yang et al. 2011).

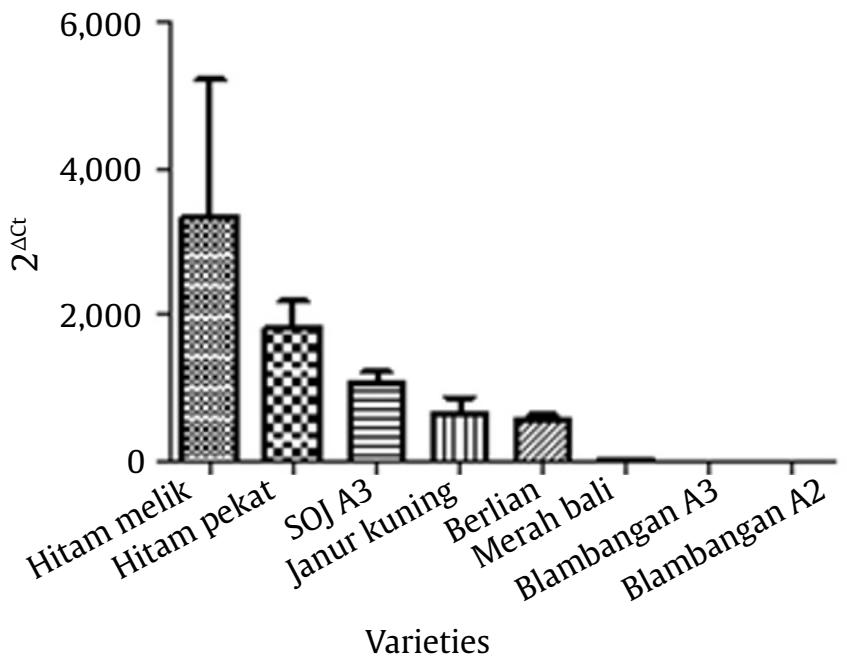

Figure 2. Relative expression of GBSSI in eight Banyuwangi local rice varieties

Table 3. Wilcoxon/Kruskal Wallis's statistical results

\begin{tabular}{lccc}
\hline Gene & Chi-square value & DF & Prob. value \\
\hline HGGT & 16.0570 & 7 & 0.0246 \\
GBSSI & 20.2000 & 7 & 0.0052 \\
\hline
\end{tabular}


Relative expression of GBSSI gene correlates with amylose level in rice seed (Fitzgerald et al. 2011; Pandey et al.2012). Based on the relative expression result showed that Hitam Melik has the highest expression of GBSSI gene, but based on physicochemical test of amylose level showed that Merah Harum and Blambangan A3 have higher amylose level than Hitam Melik (Sholikhah et al. 2018). The difference in GBSSI expression and amylose level in rice endosperm is due to the repressor that affect amylose biosynthesis (Cheng et al. 2010; Ordonio and Matsuoka 2016). Repressors are proteins that can bind to specific DNA sequences and affect the ability of polymerase RNA in gene control. When repressor is bound to the operator, the gene cannot be transcribed by polymerase RNA then it causes the amylose level in rice seed decreases even though there are many GBSSI enzymes (Ordonio and Matsuoka 2016).

\section{Conclusion}

Relative expressions of $H G G T$ in 8 varieties of Banyuwangi local rice from the highest to the lowest were Hitam Melik, Hitam Pekat, Blambangan A3, Merah Bali, Blambangan A2, Berlian, and Janur Kuning; while the GBSSI relative expression from the highest to the lowest were Hitam Melik, Hitam Pekat, SOJ A3, Janur Kuning, Berlian, Merah Bali, Blambangan A3, and Blambangan A2. Hitam Melik has the highest relative expression either the HGGT or GBSSIgene so that Hitam Melik potentially produces higher tocotrienol and lower glycemic index than other studied varieties.

\section{Conflict of Interest}

The authors claim that there is no conflict of interest. All research members had performed equal contributions.

\section{Acknowledgements}

The authors would like to extend the acknowledgements to Mr. Samanhudi, as the leader of Singojuruh Farmer Group for providing the samples and Direktorat Riset dan Pengabdian Masyarakat (DRPM) Directorate of Higher Education, Ministry of Education and Culture for supporting the funding of this research to $S^{1}$, E.S., $S^{2}$, and D.L.

\section{References}

Aggarwal BB et al. 2010. Tocotrienols, the vitamin E of the 21st Century: it's potential against cancer and other chronic diseases. Biochem Pharmacol 80:1613-1631. DOI:10.1016/j.Bcp.2010.07.043

Cheng Z et al. 2010. Diversity of Waxy gene alleles in the wild rice species of the Oryza genus. Botanical Studies 51:403-411.
Comitato R et al. 2017. Tocotrienols: a family of molecules with specific biological activities. Antioxidants 6: 14 . DOI:10.3390/antiox60 40093

Denardin CC et al. 2012. Amylose content in rice (Oryza sativa) affects performance, glycemic and lipidic metabolism in Rats. Ciencia Rural 42:381-387.

Dian FA et al. 2018. Expression of gene encoded homogentisate geranylgeranyl transferase involved in tocotrienol biosynthesis in indonesian local rice (Oryza sativa L.). AIP Conf Proc 2002:020026-1-020026-5 DOI:10.1063/1.5050122

Fitzgerald MA et al. 2011. Identification of a major genetic determinant of glycaemic index in rice. Rice 4:66-74. DOI:10.1007/s12284-011-9073-z

Jeevetha S et al. 2014. Relationship between amylose content and glycemic index of commonly consumed white rice. IOSR Journal of Agriculture and Veterinary Science 7:12-18.

Kannappan Ret al. 2012. Tocotrienols fight cancer by targeting multiple cell signaling pathways. Genes and Nutrition 7:43-52. DOI:10.1007/s12263-011-0220-3

Kozera B, Rapacz M. 2013. Reference genes in real-time PCR. AApplGenetics 54:391-406. DOI:10.1007/s13353-0130173-X

Mène-Saffrané L, dellapenna D. 2010. Biosynthesis, regulation and functions of tocochromanols in plants. Plant Physiology and Biochemistry 48:301-309. DOI:10.1016/j.plaphy.2009. 11.004

Milovanovic V, Smutka L. 2017. Asian countries in the global rice market. Acta Universitatis Agriculturae Et Silviculturae Mendelianae Brunensis 65:679-688. DOI:10.11118/acta un201765020679

Miyazawa $\mathrm{T}$ et al. 2019. Vitamin E: regulatory redox interactions. IUBMB Life 6:1-12. DOI:10.1002/ iub.2008

Ordonio RL, Matsuoka M. 2016. Increasing resistant starch content in rice for better consumer health. PNAS 113:12616-12618. DOI:10.1073/pnas.1616053113

Pandey MK et al. 2012. Different isoforms of starchsynthesizing enzymes controlling amylose and amylopectin content in rice (Oryza sativa L.). Biotechnology Advances 30:1697-1706. DOI:10.1016/j. biotechadv.2012.08.011

Ruan Y et al. 2010. Sugar input, metabolism, and signaling mediated by invertase: roles in development, yield potential, and response to drought and heat. Molecular Plant 3:942-955. DOI:10.1093/mp/ssq044

Šárka E, Dvořáček V. 2017. Biosynthesis of Waxy starch-a review. Plant Soil Environ 63:335-341. DOI:10.17221/324/2017-PSE

Shammugasamy B et al. 2015. Tocopherol and tocotrienol contents of different varieties of rice in Malaysia. Journal of the Science of Food and Agriculture. DOI:10.1002/jsfa.6742

Sholikhah A et al. 2018. Polymorphism of gene encoding granule bound starch synthase I (GBSSI) involved in starch biosynthesis in local rice from Banyuwangi. AIP Conf Proc 2002:020004-1-020004-10 DOI:10.1063/1.5050100

Sylvester PW et al. 2010. The value of tocotrienols in the prevention and treatment of cancer. Journal of the American College of Nutrition 29:324-333.

Wang W et al. 2018. Rice secondary metabolites: structures, roles, biosynthesis, and metabolic regulation. Molecules 23:1-50. DOI:10.3390/molecules23123098

Yang W et al. 2011. Vitamin E biosynthesis: functional characterization of Homogentisate Geranyl-geranyl Transferase. Plant Journal 65:206-217. DOI:10.1111/ j.1365-313X.2010.04417.x

Zhang $\mathrm{C}$ et al. 2013. Genetic and biochemical basis for alternative routes of tocotrienol biosynthesis for enhanced vitamin E antioxidant production. Plant Journal 73:628-639. DOI:10.1111/tpj.12067 